\title{
An Investigation of Polymorphism in SMO and LMF1 Genes and Their Association with Body Size in White Fulani and Muturu Cattle Breeds
}

\author{
Ridwan 0. Ahmed1*, Semiu F. Bello², Ibrahim Shu'aibu', Matthew J. Hegarty¹ \\ ${ }^{1}$ Institute of Biological, Environmental and Rural Science, Aberystwyth University, Aberystwyth, UK \\ ${ }^{2}$ Department of Animal Genetics, Breeding and Reproduction, College of Animal Science, South China Agricultural University, \\ Guangzhou, China \\ Email: *ahmedridwan341@gmail.com
}

How to cite this paper: Ahmed, R.O., Bello, S.F., Shu'aibu, I. and Hegarty, M.J. (2020) An Investigation of Polymorphism in $S M O$ and $L M F 1$ Genes and Their Association with Body Size in White Fulani and Muturu Cattle Breeds. Advances in Bioscience and Biotechnology, 11, 319-344. https://doi.org/10.4236/abb.2020.117023

Received: May 18, 2020

Accepted: July 14, 2020

Published: July 17, 2020

Copyright $\odot 2020$ by author(s) and Scientific Research Publishing Inc. This work is licensed under the Creative Commons Attribution International License (CC BY 4.0).

http://creativecommons.org/licenses/by/4.0/

(c) (i) Open Access

\begin{abstract}
Cattle production is integral to the people of Africa and her economy. To improve cattle productivity, there is a need to inculcate molecular marker-assisted selection into current breeding practices. In this study, we investigated, in White Fulani and Muturu cattle breeds, polymorphism of two candidate genes (Smoothened-SMO and Lipase Maturation Factor 1-LMF1) that have been reported to influence body size in cattle. The $S M O$ gene encodes for the SMO (smoothened) receptor protein; a membrane signal transducer that plays a role in the control of bone formation and adipogenesis. $L M F 1$ encodes for the LMF1 protein which regulates post-translational maturation of vascular lipases. Desired regions of the genes were amplified and genotyped by direct DNA sequencing or Polymerase chain reaction-Restriction Fragment Length Polymorphism. For association study, linear body measurements traits (BMTs) that can be used to predict body size were measured on each animal and values of BMTs measured were compared between both breeds. Very significant $(\mathrm{P}<0.001)$ differences, in favour of White Fulani, were observed for all the BMTs compared. Six (6) previously reported SNP (G21234C, C22424T and C22481T, T22939C, C23329T and T23458G) were found on the $S M O$ while $L M F 1$ was monomorphic at the expected $(\mathrm{T}>\mathrm{C})$ exon 4 mutation site. Association analysis revealed that polymorphism on G21234C, C22424T, T22939C and T23458G loci significantly affected BMTs $(\mathrm{P}<0.05$ or 0.01$)$ in both cattle breeds. The outcome of this study showed that $S M O$ gene could be a useful candidate gene to facilitate marker assisted selection for body size while $L M F 1$ is monomorphic in the cattle breeds.
\end{abstract}




\section{Keywords}

Smoothened, Lipase Maturation Factor 1, Body Measurement Traits, White Fulani, Muturu, Polymorphism

\section{Introduction}

Cattle production is integral to the people of Africa and her economy. It contributes $33 \%$ of the agricultural GDP in developing countries [1]. According to [2], the industry contributed $3.2 \%$ to $4 \%$ of Nigeria's overall yearly Gross Domestic Product (GDP) between 1970 to 2005. Cattle are a valuable source of protein to the people, and it represents a means of livelihood for the small-scale rural cattle owners and those involved in the cattle production value chain [3].

Over the years, researchers have used genomic tools to identify genes influencing physical traits in cattle and genetic variations that underline the differences observed between individual cattle. The $S M O$ gene has been marked as having a contributory role in skeletal tissue development and adipogenesis in both vertebrates and invertebrate [4]. It encodes for the SMO (smoothened) receptor protein; a membrane signal transducer that plays a role in the control of bone formation and adipogenesis through the hedgehog signalling pathway [4, 5]. The gene is mapped to bovine chromosome 4 with 12 exons encoding 780 amino acids [6]. The hypothesis of $S M O$ gene polymorphism affecting economically important traits in cattle was first tested by [7]. Using PCR-Restriction Fragment Length Polymorphism (RFLP), Zhang et al. [7] detected three single nucleotide polymorphisms (SNP) on the $S M O$ genes of 562 Qinchuan cattle and association studies further revealed that two out of the three polymorphic sites (G21234C and C22424T) are significantly associated with body measurement and meat quality traits. In 2015, [6] also conducted a study that confirmed the hypothesis that variation in bovine $S M O$ gene influences body size in cattle. By direct sequencing of the coding region and 3'UTR region of SMO gene in 520 Qinchuan beef cattle, they identified eight single nucleotide polymorphisms (SNP) and linkage disequilibrium analysis revealed five haplotypic groups. Collectively, SMO genes could be a useful candidate gene to be included in marker-assisted selection for cattle with superior body size during breeding programs. To the best of our knowledge, there is no information about polymorphism of this gene in African cattle.

Another candidate gene of influence on body size is the Lipase maturation factor 1 ( $L M F 1) . L M F 1$ encodes for the LMF1 protein. Paterniti et al. [8] were the first to identify the protein in mouse, where a mutation that affected LMF1 protein resulted in hyperglycaemia in mice carrying double mutant allele. This was as a result of very low levels of plasma lipases in those mice. Such abnormality has also been identified in human [9]. $L M F 1$ is located on bovine chromosome 25 [10]. Metabolism of plasma lipid is under the control of vascular lipas- 
es-lipoprotein, hepatic, and endothelial lipases. Through their action on triglycerides, they regulate the level of plasma lipid and control tissue uptake; thereby protecting the animal against cardiovascular diseases [11]. For these lipases to attain active enzymatic function, post-translational maturation of their embryonic polypeptide chain is required [12]; a process dependent on lipase maturation factor 1 (LMF1) [13]. All these processes take place in the endoplasmic reticulum of cells within lipase expression tissues such as adipose muscle and heart [14]. In cattle, [10] screened four Chinese cattle breeds-Nanyang, Qinchuan, Jiaxian, and Chinese Holstein-for a missense mutation in LMFI. Using PCR-SSCP, direct sequencing, and PCR-RFLP (AvaI endonuclease), they reported a SNP $(\mathrm{T}>\mathrm{C}$ ) in $L M F 1$ exon 4 in three of the four cattle breeds. The polymorphism was associated with growth traits in Nanyang cattle. The $\mathrm{T}>\mathrm{C}$ mutation resulted in Trp > Arg substitution in LMF1 protein. Ren et al. [10] remains the only publication of $L M F 1$ gene polymorphism and its association with growth traits in cattle.

In this study, we investigated polymorphisms of $S M O$ and $L M F 1$ genes in White Fulani and Muturu cattle breeds of Nigeria and performed association analysis to evaluate the effect of genetic variation of $S M O$ with body measurement traits. The White Fulani, a Bos indicus, is regarded as the most numerous and widespread Nigerian cattle breed representing 37\% of the country's herd [15]. The Muturu, a West African taurine, is a small-bodied trypanotolerant cattle [16]. Because routine measurements of cattle body weight can be labour intensive and not sustainable, linear body measurements are usually used as predictive measures for body weight. Traits such as heart girth and hip height have been reported to have high phenotypic and genetic correlations with body weight [17]. Ige et al. [18] reported that heart girth, horn length, body length, and hip height could be used to predict body weight in White Fulani cattle with $0.92,0.82$, 0.83 and 0.69 as their respective coefficients of determination. Dim et al. [19] reported a similar result in the same breed, emphasized that heart girth is the most reliable parameter for bodyweight prediction. Daikwo et al. [20] obtained a multiple regression equation to predict body weight of Muturu cattle from linear body measurement. Heart girth and body length accounted for $90 \%$ of the disparity in body weight; a proof that bodyweight could be predicted from the two parameters with high accuracy.

\section{Materials and Methods}

\subsection{Data Collection and Animal Source}

Forty adult cattle (19 - 24 months) each of Muturu and White Fulani were randomly selected from different livestock owners, to be as distantly related as possible. The cattle were reared under a semi-intensive system. Muturu and White Fulani were sourced from Ipokia Local Government Area, Ogun state and Oyo West Local Government Area, Oyo state Nigeria, respectively. Linear body measurements (body length, heart girth, withers height, rump length, and chest 
depth) were obtained from each animal for statistical analysis. The measurements were taken using measuring stick/tape as described by Gilbert et al. [21] and done by one person to minimize error. Using the PG-100 collection kit from PERFORMAGENE, a nasal swab was collected from each animal for DNA extraction. The study was carried out between January, 2019-September, 2019.

\subsection{Genomic DNA Extraction}

Genomic DNA was extracted from the nasal swabs following PERFORMAGENE guidelines found on https://www.dnagenotek.com/US/pdf/PD-PR-083.pdf).

\subsection{PCR Amplification}

For the two genes considered in this study, primers listed in the literature to amplify desired gene regions were ordered. Amplified regions and the expected SNP within each gene region, as reported in the literature, are presented in Table 1 . The primers were first mixed with their respective quantities of 1xTE buffer to make it up to $100 \mu \mathrm{M}$ as prescribed the primer-design company. The forward and reverse primers were then mixed and diluted to a working concentration of $10 \mu \mathrm{M}$.

Polymerase chain reaction (PCR) was performed in a $15 \mu \mathrm{L}$ reaction mixture that contained $2 \mu \mathrm{L}$ genomic DNA, $1 \mu \mathrm{M}$ primer mix, 7.5 $\mu \mathrm{L}$ PCR ImmoMix (contained magnesium chloride, DNA polymerase, and dNTPs-Bioline Ltd, UK) and $4.5 \mu \mathrm{L} \mathrm{dd} \mathrm{H}_{2} \mathrm{O}$. The PCR cycling was performed in a G-Storm GS1 thermal cycler (Akribis Scientific Limited, UK) with the following general protocols: $98^{\circ} \mathrm{C}$ for 10 mins (initial denaturation), followed by 35 cycles of denaturation at $98^{\circ} \mathrm{C}$ for $30 \mathrm{~s}, 50^{\circ} \mathrm{C}$ annealing for $30 \mathrm{~s}$, and a final extension at $72^{\circ} \mathrm{C}$ for $60 \mathrm{~s}$. The actual annealing temperature used for amplifying each gene region is presented in Table 1. PCR products were checked on $1 \%$ agarose gel.

Table 1. Primers used to amplify the target regions of each gene.

\begin{tabular}{ccccccc}
\hline Gene & $\begin{array}{c}\text { Target } \\
\text { region }\end{array}$ & SNP (s) & Primers & $\begin{array}{c}\text { Length } \\
(\mathrm{bp})\end{array}$ & A.T & Ref \\
\hline SMO & Exon 9 & G21234C & F: GCTTCACCCGTCTACTACCC & 163 & 50 & {$[7]$} \\
& & & R: GCTCATGGAAATGCCAGTTC & & & \\
& & & & & \\
Exon 11 & C22424T & F: CCTTCAAACTGGGGATGGGT & 319 & 60 & {$[7]$} \\
& & C22481T & R: ATCCATACCTGGCGTTGC & & & \\
& Exon 12 & T22939C & F: CACAGAGCTTAGAGTCCCAG & 601 & 50 & {$[6]$} \\
& & & R: AAGCCTCGGAACGGTATTTGT & & & \\
& 3'UTR & C23329T & F: CTCATGGATGCAGACTCCGAC & & 65 & {$[6]$} \\
& & T23458G & R: GTGGGTTACTGGCCTACGG & & & \\
LMF1 & Exon 4 & T27154C & F: CATCCTGCCTGGGCTCTG & 307 & 50 & {$[10]$} \\
& & & R: TCACGGGCTCAGAAACAGGT & & & \\
\hline
\end{tabular}

bp: Base pair, A.T: Annealing temperature in ${ }^{\circ} \mathrm{C}$, Ref: Reference. 


\subsection{Genotyping by PCR-Restriction Fragment Length Polymorphism}

$S M O$ exon 9 amplicon was genotyped by restriction fragment length polymorphism (RFLP) using Sau96I (New England, Biolabs) restriction enzymes. The digestion mixture-which contained aliquots of $5 \mu \mathrm{L}$ PCR product, $0.5 \mu \mathrm{L}$ restriction enzyme, $2 \mu \mathrm{L}$ Cut smart buffer, and $12.5 \mu \mathrm{L}$ dd $\mathrm{H}_{2} \mathrm{O}$-was incubated overnight at $37^{\circ} \mathrm{C}$. Digested products were electrophoresed on $2 \%$ agarose gel following the same procedure described above, except that the quantity of agarose is 3 grams.

\subsection{Amplicon Clean up}

PCR products from gene regions to be directly sequenced were first purified so that the primers and buffers are removed, leaving behind pure DNA. $60 \mu \mathrm{L}$ of ethanol/NaOAc solution ( $9375 \mu \mathrm{L} \mathrm{100 \%} \mathrm{ethanol,} 450 \mu \mathrm{L} 3 \mathrm{M}$ sodium acetate and $2175 \mu \mathrm{L}$ of $\mathrm{dd}_{2} 0$ ) was added to the $15 \mu \mathrm{L}$ PCR products. The mixture was left for 15 mins to allow for DNA precipitation, after which it was centrifuged for 45 mins at 2500 RCF. At this point, DNA had been precipitated, and the PCR plate was inverted in a centrifuge for 5 seconds to remove the solution containing primers and buffer. To remove any leftover primer, $75 \mu \mathrm{L}$ of $80 \%$ ethanol was added to each sample, centrifuged for 5 mins and inverted to remove the solution, leaving behind pure DNA. The purified DNA was diluted with $13 \mu \mathrm{L}$ dd $\mathrm{H}_{2} \mathrm{O}$.

\subsection{DNA Sequencing}

$5 \mu \mathrm{L}$ of the purified DNA sample was mixed with $2 \mu \mathrm{L}$ of diluted (1:50) forward or reverse primers. After this, it was sent for Sanger sequencing at the Institute of Biological, Environmental and Rural Science (IBERS) sequencing facility at Aberystwyth University.

Forward primer: SMO UTR

Reverse primer: $S M O 12, S M O 11, L M F 1$

\subsection{Sequence Alignment}

The sequence reads generated were search against the NCBI/GenBank database using BLAST to check the percentage identity with the gene of interest. Using Genomic Workbench software (v. 6.5, CLC Bio Ltd), multiple alignments of sequence reads from all samples were constructed to evaluate base constitution on each position and for subsequent SNP identification. The software was also used to trim low-quality reads. Base positions represented by multiple reads were identified as candidate polymorphic sites. The base-calling scores at the polymorphic sites and the number of times each base variant (allele) appeared in the samples were checked to increase confidence that the sequence variant is a true mutation, and not merely sequence error. Geneious software (version 2019.2) [22] was used to align multiple chromatograms to check for homozygosity and 
heterozygosity at the mutation sites based on the presence of double peaks at the SNP site.

\subsection{Association Study and Statistical Analyses}

The body measurement traits were linearly regressed against animals' age (19 24 months) in order to account for the effect of age differences on body size. Using the regression coefficient value from the linear regression equation, data obtained from each animal was transformed to its predicted 24-month value. The original data obtained from the field and the 24-month adjusted data is presented in Supplementary Table S6. The adopted linear regression model adopted was

$$
Y_{i}=a+b X_{i}+e_{i}
$$

where;

$Y_{i}=$ Linear body measurement, $a=$ intercept of the regression line on the $Y$-axis, $b=$ regression coefficient, $X=$ age, $e_{i}=$ random error about the regression line.

Data from Muturu and White Fulani were compared using the t-test. Allelic and genotypic frequencies for each SNP were calculated by direct counting. The genotypic frequencies were tested for deviation from Hardy-Weinberg equilibrium using Chi-square $\left(\chi^{2}\right)$ analysis. Single-factor multivariate ANOVA was used to determine the association between SNP marker and body measurement traits using SPSS software; version 24. General linear models (GLM) procedure was followed with the following model:

$$
Y_{i}=\mu+G_{i}+\varepsilon_{i}
$$

where;

$Y_{i}=$ trait measured on each individual; $\mu=$ overall mean; $G_{i}=$ fixed effect of the $i$ th genotype; and $\varepsilon_{i}=$ random error.

\section{Results}

\subsection{Regression Equation}

Presented in Table 2 is the coefficient of determination $\left(R^{2}\right)$ values for each trait regressed against age. The values were positive and above $80 \%$ except for rump length and chest depth in White Fulani, which were $73 \%$ and $64 \%$ respectively.

Table 2. Coefficient of determination ( $\mathrm{R}^{2}$ values) from the regression of each trait against age.

\begin{tabular}{ccc}
\hline Traits $(\mathrm{cm})$ & WF & Muturu \\
\hline BL & 0.86 & 0.88 \\
HG & 0.83 & 0.96 \\
WH & 0.89 & 0.91 \\
RL & 0.73 & 0.91 \\
CD & 0.64 & 0.94 \\
\hline
\end{tabular}

$\mathrm{WF}=$ White Fulani, $\mathrm{BL}=$ Body length, $\mathrm{HG}=$ Heart girth, $\mathrm{WH}=$ Wither height, $\mathrm{RL}=$ Rump length, $\mathrm{CD}=$ Chest depth. Number of observations per trait $=40$. 


\section{2. t-Test Comparing Values from Muturu and White Fulani}

Values from both breeds were compared using t-test (Table 3). Very significant $(\mathrm{P}<0.001)$ difference, in favour of White Fulani, was observed for all the traits compared.

\subsection{SMO Gene Polymorphism}

\subsubsection{SMO Exon 9}

A 163-bp region was amplified in the exon 9 of bovine $S M O$ gene. When incubated with the restriction enzyme, Sau $96 I$, to detect the G > C mutation observed at the 21,234 bp-locus in Qinchuan cattle, the PCR product produced three banding patterns representing CC, GC, and GG (Figure 1 and Figure 2). Commensurate with the result of [7], the $\mathrm{CC}$ is represented by one fragment

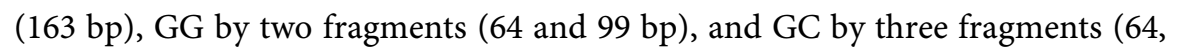
99 and $163 \mathrm{bp})$.

Allelic and genotypic frequencies were calculated for each breed (Table 4). In White Fulani, individuals with heterozygous GC genotype occurred most, followed by CC and GG, respectively. In Muturu, the heterozygous (GC) genotype,

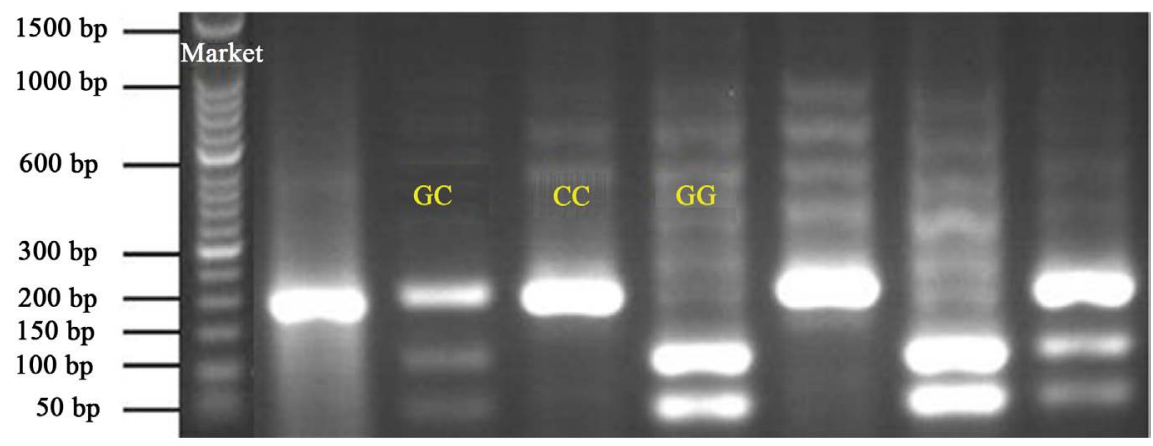

Figure 1. Gel electrophoresis showing the RFLP banding patterns for the three SMO9 genotypes in White Fulani. GC, CC and GG-observed genotypes.

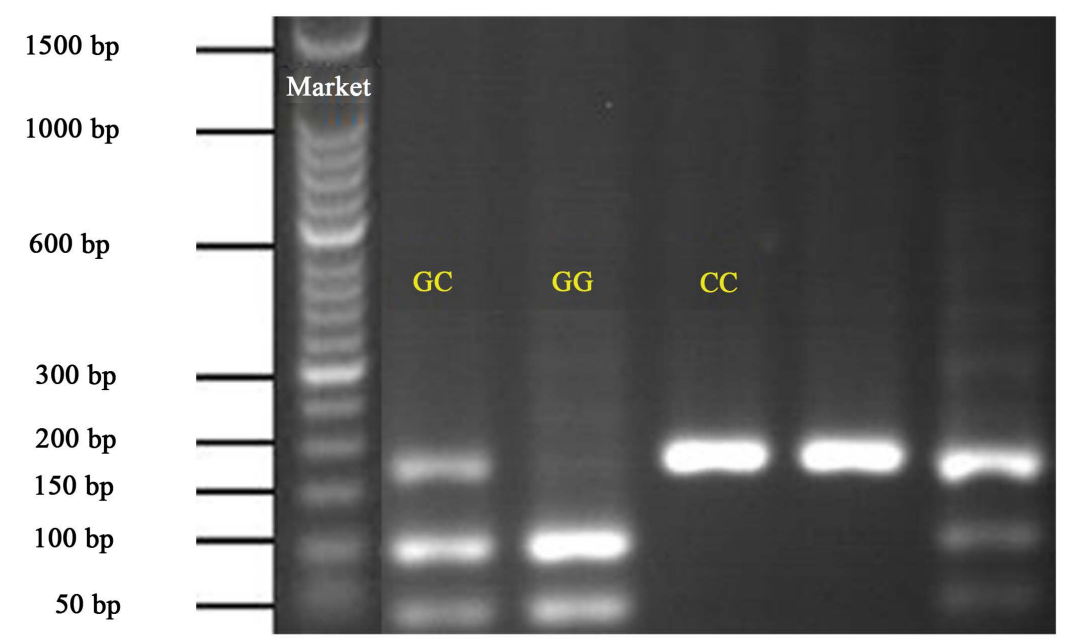

Figure 2. Gel electrophoresis showing the RFLP banding patterns for the three SMO9 genotypes in Muturu. GC, CC and GG-observed genotypes. 
Table 3. t-test comparing mean White Fulani and Muturu values for each trait.

\begin{tabular}{cccc}
\hline \multirow{2}{*}{ Traits $(\mathrm{cm})$} & \multicolumn{2}{c}{$($ Mean \pm SE) } & \multirow{2}{*}{ P values } \\
\cline { 2 - 3 } & White Fulani & Muturu & \\
\hline BL $(\mathrm{cm})$ & $133.55 \pm 0.69$ & $102.59 \pm 0.47$ & $<0.001$ \\
HG $(\mathrm{cm})$ & $155.85 \pm 0.83$ & $128.53 \pm 0.41$ & $<0.001$ \\
WH (cm) & $140.63 \pm 0.77$ & $83.52 \pm 0.37$ & $<0.001$ \\
RL (cm) & $52.60 \pm 0.67$ & $37.11 \pm 0.27$ & $<0.001$ \\
CD (cm) & $74.17 \pm 0.81$ & $55.79 \pm 0.23$ & $<0.001$ \\
\hline
\end{tabular}

All abbreviations are as described in Table 2. Number of observations per trait $=40$.

Table 4. Allelic and genotypic frequencies of G21234C SNP of SMO exon 9 gene in $\mathrm{Mu}-$ turu and White Fulani cattle.

\begin{tabular}{|c|c|c|c|c|c|c|c|c|}
\hline \multirow{2}{*}{ Breed } & \multicolumn{3}{|c|}{ Genotypic frequencies } & \multirow{2}{*}{ Total } & \multicolumn{2}{|c|}{ Allele freq. } & \multirow{2}{*}{$\operatorname{HWE}\left(\chi^{2}\right)$} & \multirow{2}{*}{ P-value } \\
\hline & $\mathrm{CC}$ & GC & GG & & $\mathrm{C}$ & G & & \\
\hline WF & $0.38(14)$ & $0.57(21)$ & $0.05(2)$ & 37 & 0.66 & 0.34 & 2.19 & 0.334 \\
\hline MUT & $0.25(9)$ & $0.39(14)$ & $0.36(13)$ & 36 & 0.44 & 0.56 & 1.824 & 0.402 \\
\hline
\end{tabular}

WF: White Fulani, MUT: Muturu, freq. Frequencies, HWE: Hardy-Weinberg equilibrium.

even though it still has the highest frequency, only occurred in one more animal when compared to the GG genotype in the population. Genotype CC had the lowest frequency of occurrence. All genotypic frequencies did not deviate from Hardy-Weinberg equilibrium.

\subsubsection{Effect of the SMO Exon 9 G21234C Polymorphism on Body Measurement Traits}

In both breeds, significant differences existed among the genotypes for all traits measured, except for rump length in White Fulani (Table 5).

\section{1) White Fulani}

Mean values for heart girth, wither height, and chest depth were significantly $(p<0.05)$ higher in genotypes GG and GC when compared with CC in White Fulani. Significant $(\mathrm{P}<0.001)$ differences existed among all the three genotypes for body length increasing from CC to GC and GG, respectively. Mean values for rump length were not significantly $(\mathrm{P}>0.05)$ different across the genotypes.

\section{2) Muturu}

In Muturu population, mean values for body length, heart girth and wither height increased significantly $(\mathrm{P}<0.001)$ and progressively from $\mathrm{CC}$ to $\mathrm{GC}$ and GG genotypes. Unlike in White Fulani where rump length was not significantly different across genotypes, GG genotype had significantly $(\mathrm{P}<0.001)$ higher rump length than GC and CC. Mean values GC and CC were not significantly (P $<0.05)$ different for rump length. For chest depth, GG genotype had significantly $(P<0.05)$ higher values than CC, but GG and GC were not significantly different. 
Table 5. Association of G21234C SNP genotypes of SMO9 gene with body measurement traits in White Fulani and Muturu cattle.

\begin{tabular}{|c|c|c|c|c|c|}
\hline \multirow{2}{*}{ Breed } & \multirow{2}{*}{$\begin{array}{c}\text { Traits } \\
(\text { means in } \mathrm{cm} \pm \mathrm{SE})\end{array}$} & \multicolumn{3}{|c|}{ Genotypes } & \multirow{2}{*}{$\mathrm{P}$-value } \\
\hline & & $\mathrm{CC}$ & GC & GG & \\
\hline \multirow[t]{5}{*}{ WF (37) } & $\mathrm{BL}$ & $130.52^{\mathrm{c}} \pm 0.94$ & $134.46^{\mathrm{b}} \pm 0.77$ & $142.68^{\mathrm{a}} \pm 2.49$ & $<0.001$ \\
\hline & $\mathrm{HG}$ & $172.72^{\mathrm{b}} \pm 1.31$ & $177.52^{\mathrm{a}} \pm 1.07$ & $178.62^{\mathrm{a}} \pm 3.48$ & 0.02 \\
\hline & WH & $143.74^{\mathrm{b}} \pm 1.20$ & $148.25^{\mathrm{a}} \pm 0.98$ & $151.92^{\mathrm{a}} \pm 3.18$ & 0.008 \\
\hline & $\mathrm{RL}$ & $50.88 \pm 1.12$ & $53.31 \pm 0.91$ & $57.16 \pm 2.96$ & 0.084 \\
\hline & $\mathrm{CD}$ & $70.95^{\mathrm{b}} \pm 1.25$ & $76.19^{\mathrm{a}} \pm 1.02$ & $78.43^{\mathrm{a}} \pm 3.30$ & 0.005 \\
\hline \multirow[t]{5}{*}{ Mut (36) } & $\mathrm{BL}$ & $99.00^{c} \pm 0.59$ & $102.51^{\mathrm{b}} \pm 0.48$ & $105.20^{\mathrm{a}} \pm 0.49$ & $<0.001$ \\
\hline & $\mathrm{HG}$ & $125.57^{\mathcal{C}} \pm 0.56$ & $128.10^{\mathrm{b}} \pm 0.45$ & $130.91^{\mathrm{a}} \pm 0.46$ & $<0.001$ \\
\hline & WH & $81.54^{\mathrm{c}} \pm 0.57$ & $83.11^{\mathrm{b}} \pm 0.45$ & $85.64^{\mathrm{a}} \pm 0.47$ & $<0.001$ \\
\hline & $\mathrm{RL}$ & $36.05^{\mathrm{b}} \pm 0.36$ & $36.78^{\mathrm{b}} \pm 0.29$ & $38.25^{\mathrm{a}} \pm 0.30$ & $<0.001$ \\
\hline & $\mathrm{CD}$ & $54.91^{\mathrm{b}} \pm 0.46$ & $55.75^{\mathrm{ab}} \pm 0.37$ & $56.41^{\mathrm{a}} \pm 0.38$ & 0.049 \\
\hline
\end{tabular}

${ }^{\mathrm{abc}}$ Means with different superscript within rows are significantly different $(\mathrm{p}<0.05$ or 0.001$)$. WF, White Fulani; Mut, Muturu; BL, Body length; HG, Heart girth; WH, Wither height; RL, Rump length; CD, Chest depth.

\subsubsection{SMO Exon 11}

319-bp of $S M O$ exon 11 gene was amplified and sequenced for 77 cattle. Geneious Prime (version 2019.2) software [22] was used to analyse the sequence map. The two SNP-C22424T and C22481T-reported by Zhang et al. [7] that caused synonymous substitution of glycine and histidine, respectively, were identified. The software allowed identification of homozygous and heterozygous genotype carriers.

For the C22424T mutation, two genotypes (CC and TT) were found in the two cattle breeds under examination (Figure 3), whereas for the C22481T mutation, White Fulani individuals had two genotypes (CC and CT) while all Muturu cattle were homozygous for the $\mathrm{C}$ allele (Figure 4).

Allelic and genotypic frequencies were calculated for each breed (Table 6). There were similarities in the allelic and genotypic distribution in both cattle breeds for C22424T polymorphism. $76 \%$ and $77 \%$ of the cattle population had the CC genotype in White Fulani and Muturu breeds, respectively. For the C22481T SNP, 86\% of the White Fulani cattle had CC genotype, while all Muturu cattle had the CC genotype (Table 6). All genotypic frequencies did not deviate from Hardy-Weinberg equilibrium.

\subsubsection{Effect of the SMO Exon 11 C22424T SNP on Body Measurement Traits \\ 1) White Fulani}

Significant difference $(\mathrm{P}<0.05)$ was observed between the two genotypesCC and TT-for all body measurement traits measured except body length (Supplementary Table S1). The difference was in favour of the CT genotype. 


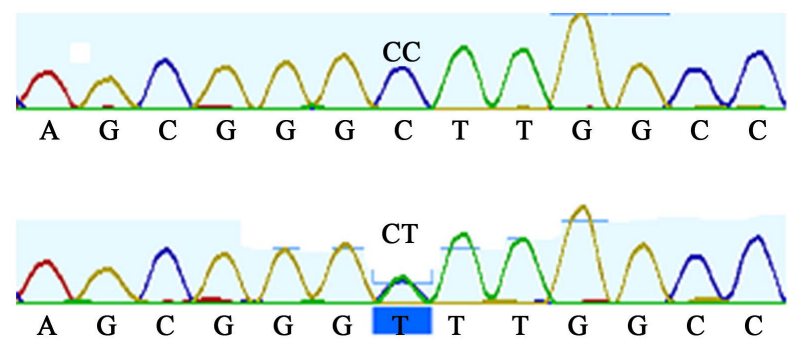

Figure 3. Sequence map showing C22424T mutation in SMO exon 11 gene.

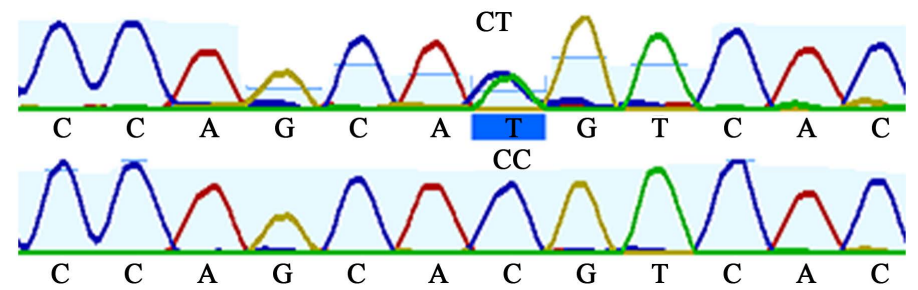

Figure 4. Sequence map showing C22481T mutation in SMO exon 11 gene.

Table 6. Allelic and genotypic frequencies of $S M O$ exon 11 polymorphisms in Muturu and White Fulani cattle.

\begin{tabular}{|c|c|c|c|c|c|c|c|}
\hline \multirow[t]{3}{*}{ Breed } & \multicolumn{2}{|c|}{ Genotypic freq. } & Total & \multicolumn{2}{|c|}{ Allele freq } & $\operatorname{HWE}\left(\chi^{2}\right)$ & P-value \\
\hline & \multicolumn{7}{|c|}{ C22424TSNP } \\
\hline & $\mathrm{CC}$ & CT & & $\mathrm{C}$ & $\mathrm{T}$ & & \\
\hline WF & $0.76(28)$ & $0.24(9)$ & 37 & 0.88 & 0.12 & 0.159 & 0.690 \\
\hline \multirow[t]{3}{*}{ MUT } & $0.77(30)$ & $0.30(9)$ & 39 & 0.88 & 0.12 & 0.157 & 0.692 \\
\hline & \multicolumn{7}{|c|}{ C22481TSNP } \\
\hline & $\mathrm{CC}$ & $\mathrm{CT}$ & & $\mathrm{C}$ & $\mathrm{T}$ & & \\
\hline WF & $0.86(32)$ & $0.14(5)$ & 37 & 0.93 & 0.07 & 0.000 & 1.000 \\
\hline MUT & $1.00(38)$ & $0.00(0)$ & 39 & 1.00 & 0.00 & 0.000 & 1.000 \\
\hline
\end{tabular}

WF: White Fulani, MUT: Muturu, freq. Frequencies, HWE: Hardy-Weinberg equilibrium.

\section{2) Muturu}

Significant differences $(\mathrm{P}<0.05)$ was only observed in body length and chest depth (Supplementary Table S1). Animals with CT genotype had significantly higher mean body length and chest depth compared to those with CC genotype.

\subsubsection{Effect of the SMO Exon 11 C22481T SNP on Body Measurement Traits}

In White Fulani breed, no significant $(\mathrm{P}>0.05)$ difference was observed between the two genotypes in all body measurement traits measured in this study (Supplementary Table S2). All Muturu cattle carry same CC genotype.

\subsubsection{SMO Exon 12}

Exon 12 of the $S M O$ gene was amplified and sequenced for 55 cattle. Using the Geneious Prime software (Version 2019.2) [22] for sequence map analysis, T22939C 
SNP [6] was identified. All the animals were genotyped for the polymorphism by direct sequencing and three genotypes-CC, $\mathrm{CT}$, and TT-were found in both cattle breeds (Figure 5).

Allelic and genotypic frequencies were calculated for each breed (Table 7). In White Fulani, $70 \%$ of the cattle had CC genotype, $27 \%$ had heterozygous CT while only one animal had the homozygous TT. Contrarily, 28\% of the Muturu cattle population carry the homozygous TT, $32 \%$ carry CC genotype while $40 \%$ had heterozygous CT. Therefore, the T-allele was more frequent in the Muturu breed $(48 \%)$ compared to White Fulani (17\%). All genotypic frequencies did not deviate from Hardy-Weinberg equilibrium.

\subsubsection{Effect of the SMO Exon 12 T22939C SNP on Body Measurement Traits}

1) White Fulani

Significant difference $(\mathrm{P}<0.05)$ was observed among the genotypes for body length and wither height. Mean values for body length and wither height in CT genotype was significantly $(\mathrm{P}<0.05)$ higher compared to CC genotype. However, TT and CT genotypes were not significantly different (Supplementary Table S3). No significant difference was observed between the three genotypes for all other traits measured.

\section{2) Muturu}

For all the traits except chest depth, mean values for cattle with TT genotype was highest $(\mathrm{P} \leq 0.001)$, followed by $\mathrm{CT}$ and the least mean value was found in cattle carrying the CC genotype (Supplementary Table S3).

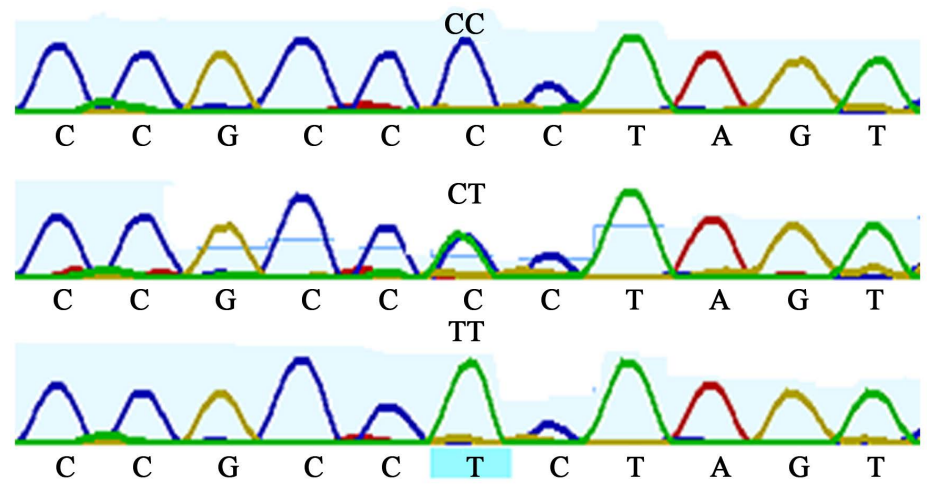

Figure 5. Sequence map showing T22939C mutation in SMO exon 12 gene.

Table 7. Allelic and genotypic frequencies of T22939C SNP of SMO exon 12 gene in Muturu and White Fulani cattle.

\begin{tabular}{|c|c|c|c|c|c|c|c|c|}
\hline \multirow{2}{*}{ Breed } & \multicolumn{3}{|c|}{ Genotypic freq. } & \multirow{2}{*}{ Total } & \multicolumn{2}{|c|}{ Allele freq. } & \multirow{2}{*}{$\operatorname{HWE}\left(\chi^{2}\right)$} & \multirow{2}{*}{ P-value } \\
\hline & $\mathrm{CC}$ & CT & TT & & $\mathrm{C}$ & $\mathrm{T}$ & & \\
\hline WF & $0.70(26)$ & $0.27(10)$ & $0.03(1)$ & 37 & 0.83 & 0.17 & 0.000 & 1.000 \\
\hline MUT & $0.32(12)$ & $0.40(16)$ & $0.29(11)$ & 39 & 0.52 & 0.48 & 1.644 & 0.439 \\
\hline
\end{tabular}

WF: White Fulani, MUT: Muturu, freq. Frequencies, HWE: Hardy-Weinberg equilibrium. 


\subsubsection{SMO 3' Untranslated Region (3'UTR)}

3' UTR region of the $S M O$ gene was amplified and sequenced for 76 cattle. Sequence mapping and genotype identification were done with Geneious Prime software (version 2019.2) [22]. Two SNP—C23329T and T23458G-reported by [6] were identified in the cattle population under examination.

Three genotypes were found for each SNP. CC, CT and TT; and TT, TG, and GG genotypes were present for C23329T and T23458G SNP respectively (Figure 6 and Figure 7).

In both breeds, allelic and genotypic distribution were similar for the two $S M O$ 3'UTR SNP. In C23329T, C-allele predominates, occurring at a frequency of 92\% and $91 \%$ in White Fulani and Muturu respectively. Only one animal per breed carried the TT homozygous (Table 8). For the T23458G SNP, T and G-alleles were prominent in both breeds; T-allele occurred in 53\% and 57\% of the White Fulani and Muturu cattle respectively (Table 8). All genotypic frequencies did not deviate from Hardy-Weinberg equilibrium.
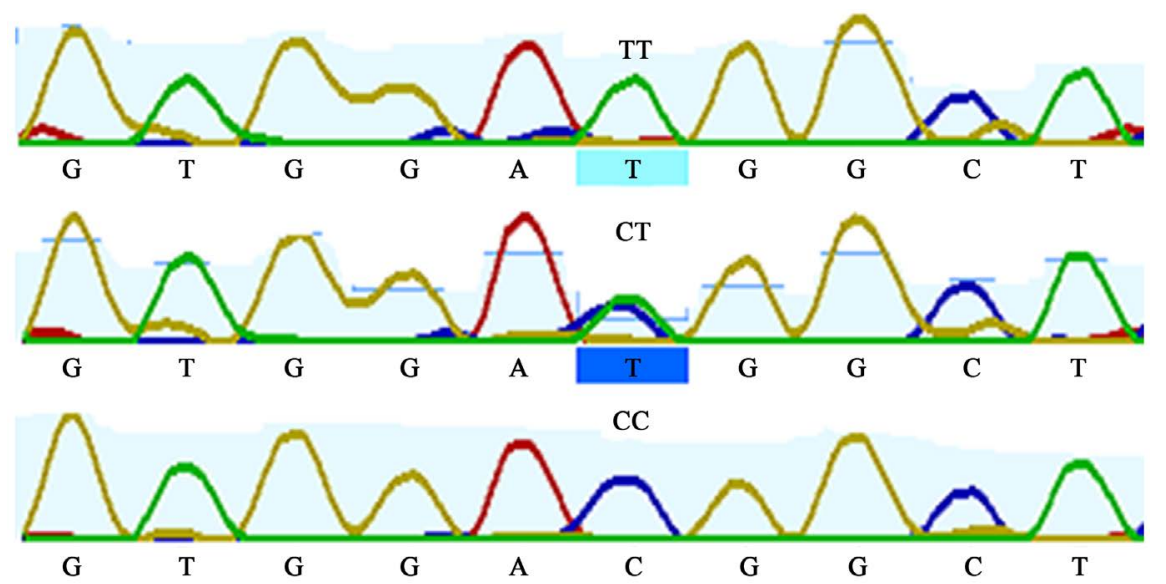

Figure 6. Sequence map showing C23329T mutation in SMO3UTR region.

Table 8. Allelic and genotypic frequencies of $S M O 3^{\prime}$ UTR polymorphisms in Muturu and White Fulani cattle.

\begin{tabular}{|c|c|c|c|c|c|c|c|c|}
\hline \multirow[t]{3}{*}{ Breed } & \multicolumn{3}{|c|}{ Genotypic freq. } & Total & \multicolumn{2}{|c|}{ Allele freq. } & $\operatorname{HWE}\left(\chi^{2}\right)$ & P-value \\
\hline & \multicolumn{8}{|c|}{ C23329T SNP } \\
\hline & $\mathrm{CC}$ & $\mathrm{CT}$ & TT & & $\mathrm{C}$ & $\mathrm{T}$ & & \\
\hline WF & $0.87(34)$ & $0.10(4)$ & $0.03(1)$ & 39 & 0.92 & 0.08 & 0.230 & 0.891 \\
\hline \multirow[t]{3}{*}{ MUT } & $0.84(31)$ & $0.14(5)$ & $0.03(1)$ & 37 & 0.91 & 0.09 & 0.200 & 0.905 \\
\hline & \multicolumn{8}{|c|}{ T23458G SNP } \\
\hline & TT & TG & GG & & $\mathrm{T}$ & G & & \\
\hline WF & $0.34(13)$ & $0.37(14)$ & $0.29(11)$ & 38 & 0.53 & 0.47 & 1.697 & 0.428 \\
\hline MUT & $0.40(14)$ & $0.34(12)$ & $0.26(9)$ & 35 & 0.57 & 0.43 & 3.304 & 0.192 \\
\hline
\end{tabular}

WF: White Fulani, MUT: Muturu, freq. Frequencies, HWE: Hardy-Weinberg equilibrium. 


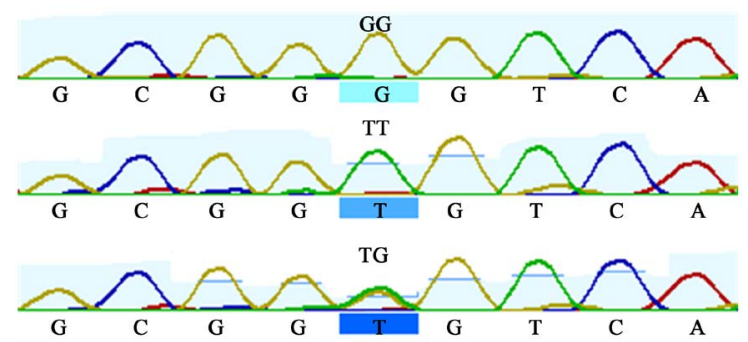

Figure 7. Sequence map showing T23458G mutation in SMO3'UTR region.

\subsubsection{Effect of the SMO 3'UTR C23329T SNP on Body Measurement Traits}

In both breeds, no significant $(\mathrm{P}>0.05)$ difference was found between the three genotypes for all the body measurement traits (Supplementary Table S4).

\subsubsection{Effect of the $S M O 3^{\prime}$ UTR T23458G SNP on Body Measurement Traits}

Contrary to the no-effect obtained in C23329T SNP, significant difference existed between the genotypes for the T23458G SNP.

\section{1) White Fulani}

Mean values for body length and wither height were significantly $(\mathrm{P}<0.01$ or $\mathrm{P}<0.05)$ different across the genotypes. Values for TT and TG were similar but significantly greater than values for GG in both body length and wither height (Supplementary Table S5). No significant difference was found between the three genotypes in all other traits measured.

\section{2) Muturu}

There was a significant difference $(\mathrm{P}<0.01)$ between the genotypes for all body measurement traits except chest depth. Cattle with TT genotype had significantly (P $<0.01$ ) higher mean values for body length, heart girth, wither height, and rump length when compared to those with GG genotype (Supplementary Table S5).

\subsection{Effect of the $L M F 1$ Exon 4 T27154C SNP on Body Measurement Traits}

Using primers listed above, 307-bp of $L M F 1$ exon 4 covering the T27154C polymorphic site reported by Ren et al. [10] in Chinese cattle was amplified and sequenced for 74 African cattle. Sequence analysis was done with Geneious software (version 2019.2). At the T27154C mutation point, only homozygous $\mathrm{T}$-allele were found (Figure 8). In the population of White Fulani (38) and Muturu (36) examined in this study, all animals had a fixed T-allele, and genotypic frequency for TT was 1.0.

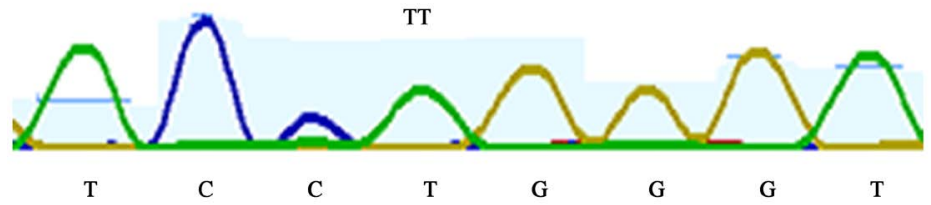

Figure 8. Sequence map showing absence of T27154C mutation on LMF1 exon 4 region. 


\section{Discussion}

\subsection{Regression Equation}

The coefficient of determination $\left(\mathrm{R}^{2}\right)$ values for all the traits regressed against age were positive and above $80 \%$ except for rump length and chest depth in White Fulani, which were $73 \%$ and $64 \%$ respectively. This suggests that, unlike in Muturu breed, age difference only accounted for a relatively smaller component of the variations in rump length and chest depth between White Fulani cattle. Such distinctions observed between cattle breeds might be as a result of breed to breed differences in the shape of measured traits. Berge et al. [23] noted that curvature of the first rib, around where chest depth is measured, varies across breeds. Variations in the shape of rump between the breeds have been reported. While the taurine breed has a well-muscled and more horizontal rump [24], White Fulani rump gently slopes downward from hook to pin bone [25]. In general, the regression equations can be used to make predictions for values of body measurement traits with a moderate to high degree of confidence. This agrees with the findings of [26] where age of cattle significantly accounted for the differences in linear body measurement values (body length, height at wither, heart girth) in Muturu and White Fulani cattle. Bene [27] also reported a moderate correlation (up to 0.46 ) between age of animal and body measurement traits in nine cattle breeds.

\section{2. t-Test Comparing Values of White Fulani and Muturu}

Mean values for all body measurement traits were significantly higher in White Fulani compared to Muturu. This is not unexpected as the highly varied body size of both cattle breeds is well documented. Udeh [28] reported that at $\mathrm{P}<$ 0.01 , body measurement traits (heart girth, withers height, and body length) were significantly greater in zebu breed than Muturu. In the research conducted by [26], body measurements-live weight, head length, head width, body length, height at wither and heart girth-were significantly $(\mathrm{P}<0.05)$ greater in White Fulani compared to Muturu.

\subsection{SMO Polymorphisms and Their Association with Body Measurement Traits (BMTs)}

As a result of its association with BMTs in other cattle breeds [6,7], the $S M O$ gene was investigated here in White Fulani and Muturu breed. No study has tried to investigate this.

\subsection{SMO9 Polymorphism and Its Association with BMTs}

Although with different allelic and genotype distribution, the G21234C SNP in bovine $S M O$ exon 9 was found in both breeds under investigation. The G-allele had a higher occurrence in Muturu (56\%) compared to 34\% in White Fulani. In agreement with the findings of [7], association analysis revealed that the G21234C polymorphism affected body length, heart girth, wither height, and chest depth 
in both breeds. It was also associated with rump length in Muturu, but not in White Fulani cattle. The non-significant effect of SMO9 on rump length observed in White Fulani might not be unconnected to the relatively low coefficient of regression obtained when age was regressed on rump length, as described above. From the association result, the G allele and GG homozygous genotype are favourable for selection to improve body measurement traits in both breeds. In both breeds, GG genotype was superior to CC in certain body measurement traits (BL, HG, WH and CD). In Muturu, homozygous GG genotype had significantly $(\mathrm{P}<0.05)$ higher mean values than the heterozygous GC genotype for all traits except chest depth, unlike in White Fulani where mean values for the GG and GC genotypes were not significantly different for those traits. The results for White Fulani closely match the outcome observed in Qinchuan cattle where homozygous GG cattle had the same mean BMTs as those with heterozygous $\mathrm{GC}^{7}$. It is equally important to note that the GG genotype only appeared twice in the White Fulani population under study. This low GG genotype might be as a result of the small sample size used for this study. In all, this finding revealed that genetic improvement program should focus on using selection to increase $G$ allele in the population.

As reported by [7], the G21234C SNP results in synonymous substitution of arginine, thereby not altering the amino acid sequence of the translated protein. This is not expected to alter the function of the SMO protein. However, influence of the SNP on body measurement traits observed can be explained by codon bias. This change in codon (G/C), although does not affect amino acid sequence, could affect the timing of translation from gene to protein $[29,30]$, thereby altering protein function and structure. This could be the scenario affecting mRNA translation into SMO protein, which then influenced the transmission of hedgehog signals. It has also been reported that through interaction with RNA-binding proteins, such silent mutation can have a regulatory effect on post-translational gene expression [31, 32]. Furthermore, non-synonymous SNP can also influence DNA methylation in epigenetic regulation [33].

\subsection{SMO Exon 11 Polymorphisms and Its Association with BMTs}

\subsubsection{G222424T}

White Fulani and Muturu cattle population studied had two genotypes-CC and CT. Homozygous TT was absent in both breeds. In Qinchuan cattle, [7] found all the possible three genotypes. Absence of TT genotype in this study is likely to be due to the small sample size. Statistical analysis revealed that mean values for four BMTs in White Fulani (heart girth, wither height, rump length and chest depth) and two BMTs in Muturu (body length and chest depth) were significantly $(\mathrm{P}<0.05)$ greater in cattle with CT genotype compared to those with TT genotype. This finding agrees with what was reported by [7] where cattle with CT genotype had significantly higher mean values for body measurement traits relative to those with CC and TT genotype. Although the C > T SNP only resulted in synonymous glycine mutation in the SMO protein, studies have re- 
vealed that such mutation can also affect protein function and structure as previously explained above in $S M O$ exon 9 polymorphism. It appears that the heterozygous CT genotype is favourable for superior body measurement traits in the breeds. Therefore, conscious selection and breeding program should be put in place to increase the frequency of this genotype in the Muturu and White Fulani cattle population.

\subsubsection{C22481T}

In White Fulani, both CC and CT genotypes were found with CC occurring more frequently. TT genotype was absent just as it was in Qinchuan cattle [7]. Only the CC genotype was found in Muturu cattle. This represents a clear distinction between the White Fulani and Muturu cattle population studied. The absence of the T-allele in Muturu cattle might be due to the low sample size, or the C22481T mutation has not happened in the breed. The mutation resulted in a synonymous histidine substitution, as noted by [7]. Association studies in White Fulani revealed that no significant $(\mathrm{P}>0.05)$ difference exist between $\mathrm{CC}$ and $\mathrm{CT}$ genotype for all the body measurement traits. This result tallies with the outcome from [7] that the C22481T polymorphism does not affect body measurement traits. A plausible explanation offered was that the effect of CC and CT genotype on mRNA translation to SMO protein, and on the protein structure, was of equal proportion. This SNP can therefore not be used for marker-assisted selection.

\subsection{SMO Exon 12 T22939C Polymorphism and Its Association with BMTs}

Three genotypes-CC, CT, and TT-were identified in both Muturu and White Fulani breeds for the C22939T SNP. The T-allele frequency was $17 \%$ and $48 \%$ in White Fulani and Muturu breed respectively. TT-genotypic frequency of $28 \%$ in Muturu compared to $3 \%$ in White Fulani exemplified the relative abundance of the T-allele in Muturu cattle population. Statistical analysis revealed that mean values for body length and wither height were significantly $(\mathrm{P}<0.05)$ greater in White Fulani cattle carrying CT and TT genotypes when compared to those with the CC genotype. In Muturu, mean values for individuals with TT genotype was very significantly $(\mathrm{P}<0.001)$ greater than those with $\mathrm{CC}$ and $\mathrm{CT}$ genotypes for all the body measurement traits except chest depth. Taken together, it appears that selection to increase the frequency of $\mathrm{T}$-allele in the population will be beneficial to attain superior body measurement traits. In Qinchuan breed studied by [6], cattle with $\mathrm{C}$-allele had significantly $(\mathrm{P}<0.05)$ lower body size traits compared to those with the T-allele. Zhang et al. [6] reported that this $\mathrm{T}>\mathrm{C}$ polymorphism resulted in a non-synonymous serine to proline amino acid substitution in the c-terminal of bovine $S M O$ protein. Without mutation, activation of the SMO protein is triggered by phosphorylation of serine-threonine residue at the c-terminal end of the protein [34]. A substitution of serine to proline will not permit phosphorylation, which will invariably inactivate SMO protein. Therefore, this protein inactivation might be the basis for cattle with the $\mathrm{C}$-allele hav- 
ing lower body measurement traits. The protein, which is a membrane signal transducer, plays a role in the control of bone formation and adipogenesis through the hedgehog signalling pathway [4].

\subsection{SMO 3'UTR Polymorphisms and Its Association with BMTs}

\subsubsection{C23329T}

White Fulani and Muturu cattle population examined had CC, CT, and TT genotypes. Allelic and genotypic distribution were similar in both breeds with C-allele predominating ( $92 \%$ and $91 \%$ in White Fulani and Muturu breed respectively). Homozygous TT only appeared in one of the sampled animals per breed. This suggests that this $C>T$ mutation is not widely spread in Nigeria's White Fulani and Muturu cattle. Statistical analysis revealed that no significant $(\mathrm{P}>0.05)$ difference existed between the three genotypes for this SNP in both breeds. This result is not in tandem with what was observed in Chinese Qinchuan cattle by Zhang et al. [6]. Animals with CC genotype had significantly (P $<0.05)$ larger body measurement traits when compared to those with TT genotype in Qinchuan cattle. The absence of this SNP effect on body measurement traits here might arise from the very low frequency of occurrence of T-allele in both breeds under examination. It could also be that this SNP does not have an effect on body measurement traits in Nigeria's White Fulani and Muturu breeds, and as such cannot be as molecular marker for cattle selection. The best practice is to examine the effect of a marker on a breed using a large population of that breed, as it is not unusual to find inconsistencies between different studies that utilized different breeds [35]. Therefore, a larger sample size is needed to confirm the veracity of this result.

\subsubsection{T23458G}

Contrary to the dominance of one allele found in the C23329T SNP, both T and G-alleles of the T23458G SNP of SMO 3'UTR have appreciable occurrence in both breeds. T-allele frequency was $53 \%$ and $57 \%$ in White Fulani and Muturu respectively. This shows that the $\mathrm{T}>\mathrm{G}$ mutation on the 3'UTR region of SMO has been fully established in both breeds. Also, as opposed to the no-effect of the C23329T SNP, T23458G SNP has a significant influence on body measurement traits in both cattle breeds. In White Fulani, individuals with TT genotype had significantly $(\mathrm{P}<0.05)$ greater mean values for body length and wither height when compared to those with CC genotype. In the same vein, Muturu cattle with TT genotype had significantly $(\mathrm{P}<0.01)$ greater body length, heart girth, wither height, and rump length relative to those with CC genotype. Taken together, it will be beneficial to increase the T-allele in the population to achieve superior body measurement traits. It can be argued that since this SNP is in the gene's non-coding region, it should not normally influence the protein function. However, studies have indicated that mutation on the 3'UTR region could influence gene expression pattern. $[36,37]$ are examples of studies that have shown a positive influence of 3'UTR sequence mutation of gene expression pattern. Stacho- 
wiak et al. [37] showed that a mutation in the 3'UTR region of PPARA gene influenced transcript level of the gene, and subsequently had significant influence of adipose tissue accumulation in pig.

\subsubsection{LMF1 Polymorphism and Its Association with BMTs}

All animals in both breeds investigated for the T27154C SNP were monomorphic and homozygous for the T-allele. Ren et al. [10] had associated this SNP with body size in Chinese Nanyang cattle. It appears that Nigerian cattle-both taurine and indicine-are monomorphic at the mutation site or genetic drift has resulted in the loss of this variation. In Chinese Holstein cattle breed screened by [10], all the animals were also monomorphic and homozygous for the T-allele at the $27154 \mathrm{~T}>\mathrm{C}$ site. Ren et al. [10] offered an explanation that C-allele of the $\mathrm{C}>\mathrm{T}$ polymorphism might only be found in meat-type cattle breeds considering that Chinese Holstein, which is not polymorphic at the mutation site, was the only dairy breed out of the four cattle breeds examined. It is difficult to infer the same explanation for result of this study as Muturu and White Fulani cattle have not been specialized. Overall, based on the findings of this study revealing lack of polymorphism within both breeds, $L M F 1$ exon 4 mutation cannot be associated with growth traits in these breeds, and can therefore not be used for marker-assisted selection. However, this conclusion is limited to the outcome of this study; further research is needed before it can be confirmed or refuted.

\section{Conclusion}

In this study, we've showed evidence of polymorphism of $S M O$ gene in White Fulani and Muturu cattle breeds. In addition, we report that variations at G21234C, C22424T, T22939C and T23458G loci significantly affected BMTs in both cattle breeds. However, evidence suggests the absence of $L M F 1$ polymorphism in the two African cattle breeds.

\section{Acknowledgements}

I'm indebted to the Commonwealth Scholarship Commission and Aberystwyth University who provided sponsorship for my MSc degree in Aberystwyth University where the research was conducted. My appreciation also goes to my Supervisor, Dr Matthew Hegarty, for guiding me through the processes. I'm grateful to Mr Oladiti Ridwan, Moibi Adeyemi, Adeniyi Abdul-Ganiy and Amune Jeremiah for their assistance during the execution of the field work.

\section{Authors Contribution}

MJ Hegarty supervised the whole process. Ridwan Olawale Ahmed designed the experiment, carried out laboratory works, did the statistical analysis. Ridwan Olawale Ahmed and Ibrahim Shu'aibu wrote the manuscript. Semiu Folaniyi Bello collected field data-collection of nasal swabs and morphological data from cattle. All authors read and approved the manuscript. 


\section{Conflicts of Interest}

The authors declare no conflicts of interest regarding the publication of this paper.

\section{References}

[1] Thornton, P.K. (2010) Livestock Production: Recent Trends, Future Prospects. Philosophical Transactions of the Royal Society: Biological Sciences, 365, 2853-2867. https://doi.org/10.1098/rstb.2010.0134

[2] Ojiako, I.A. and Olayode, G.O. (2008) Analysis of Trends in Livestock Production in Nigeria: 1970-2005. Journal of Agriculture and Social Research, 8, 114-120. https://www.ajol.info/index.php/jasr/article/view/2892 https://doi.org/10.4314/jasr.v8i1.2892

[3] Okunmadewa, F. (1999) Livestock Industry as a Tool for Poverty Allevation. Nigerian Journal of Animal Science, 2, 1-7. https://doi.org/10.4314/tjas.v2i2.49678 https://www.ajol.info/index.php/tjas/article/view/49678

[4] McMahon, A.P., Ingham, P.W. and Tabin, C.J. (2003) Developmental Roles and Clinical Significance of Hedgehog Signaling. Current Topics in Developmental Biology, 53, 1-114. https://doi.org/10.1016/S0070-2153(03)53002-2 https://www.sciencedirect.com/science/article/abs/pii/S0070215303530022

[5] Suh, J.M., Gao, X., McKay, J., McKay, R., Salo, Z. and Graff, J.M. (2006) Hedgehog Signaling Plays a Conserved Role in Inhibiting Fat Formation. Cell Metabolism, 3, 25-34. https://www.sciencedirect.com/science/article/pii/S1550413105003487 https://doi.org/10.1016/j.cmet.2005.11.012

[6] Zhang, Y.R., Gui, L.S., Li, Y.K., Jiang, B.J., Wang, H.C., Zhang, Y.Y. and Zan, L.S. (2015) Molecular Characterization of Bovine SMO Gene and Effects of Its Genetic Variations on Body Size Traits in Qinchuan Cattle (Bostaurus). International Journal of Molecular Sciences, 16, 16966-16980. https://doi.org/10.3390/ijms160816966 https://www.mdpi.com/1422-0067/16/8/16966/htm

[7] Zhang, Y.R., Li, Y.K., Fu, C.Z., Wang, J.L., Wang, H.B. and Zan, L.S. (2014) Effects of Bovine SMO Gene Polymorphisms on the Body Measurement and Meat Quality Traits of Qinchuan Cattle. Genetics and Molecular Research, 13, 8105-8117. https://pdfs.semanticscholar.org/d208/5e7e7f631e948fd0e7eadcc35d8f7816e4c9.pdf https://doi.org/10.4238/2014.October.7.5

[8] Paterniti, J.R., Brown, W.V., Ginsberg, H.N. and Artzt, K. (1983) Combined Lipase Deficiency (cld): A Lethal Mutation on Chromosome 17 of the Mouse. Science, 221, 167-169. https://science.sciencemag.org/content/221/4606/167 https://doi.org/10.1126/science.6857276

[9] Ben-Zeev, O., Hosseini, M., Lai, C.M., Ehrhardt, N., Wong, H., Cefalù, A.B., Péterfy, M., et al. (2011) Lipase Maturation Factor 1 Is Required for Endothelial Lipase Activity. Journal of Lipid Research, 52, 1162-1169.

https://www.jlr.org/content/52/6/1162.short https://doi.org/10.1194/jlr.M011155

[10] Ren, G., Liu, J.X., Li, F., Lan, X.Y., Li, M.J., Zhang, Z.Y. and Chen, H. (2011) A Novel Missense Mutation of Bovine Lipase Maturation Factor 1 (LMF1) Gene and Its Association with Growth Traits. African Journal of Biotechnology, 10, 75627566. https://www.ajol.info/index.php/ajb/article/view/94814

[11] Young, S.G. and Zechner, R. (2013) Biochemistry and Pathophysiology of Intravascular and Intracellular Lipolysis. Genes \& Development, 27, 459-484. 
http://genesdev.cshlp.org/content/27/5/459.short

https://doi.org/10.1101/gad.209296.112

[12] Doolittle, M.H. and Péterfy, M. (2010) Mechanisms of Lipase Maturation. Clinical Lipidology, 5, 117-130. https://doi.org/10.2217/clp.09.84

[13] Péterfy, M., Ben-Zeev, O., Mao, H.Z., Weissglas-Volkov, D., Aouizerat, B.E., Pullinger, C.R., Pajukanta, P., et al. (2007) Mutations in LMF1 Cause Combined Lipase Deficiency and Severe Hypertriglyceridemia. Nature Genetics, 39, 1483.

https://www.nature.com/articles/ng.2007.24 https://doi.org/10.1038/ng.2007.24

[14] Ben-Zeev, O., Doolittle, M.H., Davis, R.C., Elovson, J. and Schotz, M.C. (1992) Maturation of Lipoprotein Lipase. Expression of Full Catalytic Activity Requires Glucose Trimming But Not Translocation to the Cis-Golgi Compartment. Journal of Biological Chemistry, 267, 6219-6227.

https://www.jbc.org/content/267/9/6219.short

[15] Alphonsus, C., Akpa, G.N. and Barje, P.P. (2012) Comparative Evaluation of Linear Udder and Body Conformation Traits of Bunaji and Friesian x Bunaji Cows. World Journal of Life Science Medical Research, 2, 134-140. https://www.ajol.info/index.php/ari/article/view/79799

[16] Maule, J.P. (1990) The Cattle of the Tropics. University of Edinburgh Centre for Tropical Veterinary Medicine, Edinburgh.

[17] Koenen, E.P.C. and Groen, A.F. (1998) Genetic Evaluation of Body Weight of Lactating Holstein Heifers Using Body Measurements and Conformation Traits. Journal of Dairy Science, 81, 1709-1713. https://doi.org/10.3168/jds.S0022-0302(98)75738-8 https://www.sciencedirect.com/science/article/pii/S0022030298757388

[18] Ige, A.O., Adedeji, T.A., Ojedapo, L.O., Obafemi, S.O. and Ariyo, O.O. (2015) Linear Body Measurement Relationship in White Fulani Cattle in Derived Savannah Zone of Nigeria. Journal of Biological Agriculture Healthcare, 5, 1-6. https://pdfs.semanticscholar.org/4360/0d580020440e179cc7759635c7ce8bbf60b0.pdf

[19] Dim, N.I., Egahi, J.O. and Tanko, M.U. (2012) Zoometrical Measurements of Body Parts and Their Relationship with Live Weight in Bunaji Cows in Zaria, Nigeria. International Journal of Advanced Biological Research, 2, 339-341. http://scienceandnature.org/IJABR_Vol2(2)2012/IJABR_V2(2)27.pdf

[20] Daikwo, S.I., Ogah, D.M., Amuda, A.J. and Dike, U.A. (2018) Prediction of Body Weight of SavannaMuturu Cattle (Bosbrachyceros). Asian Journal of Research in Animal and Veterinary Sciences, 2, 1-6. http://journalajravs.com/index.php/AJRAVS/article/view/293

[21] Gilbert, R.P., Bailey, D.R. and Shannon, N.H. (1993) Linear Body Measurements of Cattle before and after 20 Years of Selection for Postweaning Gain When Fed Two Different Diets. Journal of Animal Science, 71, 1712-1720.

https://academic.oup.com/jas/article-abstract/71/7/1712/4632342 https://doi.org/10.2527/1993.7171712x

[22] Kearse, M., Moir, R., Wilson, A., Stones-Havas, S., Cheung, M., Sturrock, S., Thierer, T., et al. (2012) Geneious Basic: An Integrated and Extendable desktop Software Platform for the Organization and Analysis of Sequence Data. Bioinformatics, 28, 1647-1649. https://academic.oup.com/bioinformatics/article/28/12/1647/267326 https://doi.org/10.1093/bioinformatics/bts199

[23] Berge, S. (1977) On the Estimation of Weight and Increase of Weight by Means of the Chest Girth in Norwegian Red Cattle at the Agricultural University at Ås, Nor- 
way in the Years 1972 and 1974. Acta Agriculturae Scandinavica, 27, 65-66. https://www.tandfonline.com/doi/abs/10.1080/00015127709435110?journalCode=sa ga19 https://doi.org/10.1080/00015127709435110

[24] Hoste, C.H., Chalon, E., d'leteren, G. and Trail, J.C.M. (1992) Trypanotolerant Livestock in West \& Central Africa (Vol. 3). International Livestock Centre for Africa, Addis Ababa.

[25] Tawah, C.L. and Rege, J.E.O. (1996) White Fulani Cattle of West and Central Africa. Animal Genetic Resources, 17, 127-145. https://doi.org/10.1017/S101423390000064X

https://www.cambridge.org/core/journals/animal-genetic-resources-resources-genetiq ues-animales-recursos-geneticos-animales/article/white-fulani-cattle-of-west-and-cen tral-africa/E6A2FE9D075EA71FE823E9011F97A1A1

[26] Oduguwa, B.O., Adedeji, A.A., Sowande, S.O., Isah, O.A. and Amole, T.A. (2013) Estimation of Live Weight from Linear Body Measurements of Three African Breeds of Cattle under Extensive Management System in Nigeria. Nigerian Journal of Animal Science, 15, 1-9. https://www.ajol.info/index.php/tjas/article/view/94026

[27] Bene, S., Nagy, B., Nagy, L., Kiss, B.A., Polgar, J.P. and Szabo, F. (2007) Comparison of Body Measurements of Beef Cows of Different Breeds. Archives Animal Breeding, 50, 363-373. https://d-nb.info/1148700862/34 https://doi.org/10.5194/aab-50-363-2007

[28] Udeh, I., Akporhuarho, P.O. and Onogbe, C.O. (2011) Phenotypic Correlations among Body Measurements and Physiological Parameters in Muturu and Zebu Cattle. Journal of Agricultural and Biological Science, 6, 1-4. https://www.cabdirect.org/cabdirect/abstract/20113231829

[29] Liu, Q., Dou, S., Ji, Z. and Xue, Q. (2005) Synonymous Codon Usage and Gene Function Are Strongly Related in Oryzasativa. Biosystems, 80, 123-131. https://www.sciencedirect.com/science/article/pii/S0303264704002114 https://doi.org/10.1016/j.biosystems.2004.10.008

[30] Kimchi-Sarfaty, C., Oh, J.M., Kim, I.W., Sauna, Z.E., Calcagno, A.M., Ambudkar, S.V. and Gottesman, M.M. (2007) A "Silent" Polymorphism in the MDR1 Gene Changes Substrate Specificity. Science, 315, 525-528.

https://science.sciencemag.org/content/315/5811/525/tab-pdf https://doi.org/10.1126/science.1135308

[31] Glisovic, T., Bachorik, J.L., Yong, J. and Dreyfuss, G. (2008) RNA-Binding Proteins and Post-Transcriptional Gene Regulation. FEBS Letters, 582, 1977-1986. https://doi.org/10.1016/j.febslet.2008.03.004

[32] Shabalina, S.A., Spiridonov, N.A. and Kashina, A. (2013) Sounds of Silence: Synonymous Nucleotides as a Key to Biological Regulation and Complexity. Nucleic Acids Research, 41, 2073-2094. https://doi.org/10.1093/nar/gks1205 https://academic.oup.com/nar/article/41/4/2073/2414416

[33] Shilpi, A., Bi, Y., Jung, S., Patra, S.K. and Davuluri, R.V. (2017) Identification of Genetic and Epigenetic Variants Associated with Breast Cancer Prognosis by Integrative Bioinformatics Analysis. Cancer Informatics, 16, CIN-S39783.

https://journals.sagepub.com/doi/pdf/10.4137/CIN.S39783 https://doi.org/10.4137/CIN.S39783

[34] Apionishev, S., Katanayeva, N.M., Marks, S.A., Kalderon, D. and Tomlinson, A. (2005) Drosophila Smoothened Phosphorylation Sites Essential for Hedgehog Signal Transduction. Nature Cell Biology, 7, 86.

https://www.nature.com/articles/ncb1210.pdf 
https://doi.org/10.1038/ncb1210

[35] Rischkowsky, B. and Pilling, D. (2007) Genetic Improvement Methods to Support Sustainable Utilization. Section D. In: The State of the Worlds Genetic Resources for Food and Agriculture, FAO, Rome, 380-422.

http://www.fao.org/docrep/010/a1250e/a1250e00.htm

[36] Clop, A., Marcq, F., Takeda, H., Pirottin, D., Tordoir, X., Bibé, B., Larzul, C., et al. (2006) A Mutation Creating a Potential Illegitimate microRNA Target Site in the Myostatin Gene Affects Muscularity in Sheep. Nature Genetics, 38, 813.

https://www.nature.com/articles/ng1810.pdf

https://doi.org/10.1038/ng1810

[37] Stachowiak, M., Szydlowski, M., Flisikowski, K., Flisikowska, T., Bartz, M., Schnieke, A. and Switonski, M. (2014) Polymorphism in 3' Untranslated Region of the Pig PPARA Gene Influences Its Transcript Level and Is Associated with Adipose Tissue Accumulation. Journal of Animal Science, 92, 2363-2371.

https://academic.oup.com/jas/article/92/6/2363/4701500 https://doi.org/10.2527/jas.2013-7509 


\section{Supplementary Data}

Table S1. Association of C22424T SNP genotypes of SMO exon 11 gene with body measurement traits in White Fulani and Muturu cattle.

\begin{tabular}{ccccc}
\hline \multirow{2}{*}{ Breed } & Traits & \multicolumn{2}{c}{ Genotype } & \multirow{2}{*}{ P-value } \\
\cline { 3 - 4 } WF (37) & BL & CC & CT & \\
\cline { 3 - 4 } & HG & $133.44 \pm 0.83$ & $134.51 \pm 1.47$ & 0.533 \\
& WH & $175.00^{\mathrm{a}} \pm 0.98$ & $179.12^{\mathrm{b}} \pm 1.74$ & 0.047 \\
& RL & $51.78^{\mathrm{a}} \pm 0.78$ & $55.47^{\mathrm{b}} \pm 1.37$ & 0.025 \\
& CD & $73.12^{\mathrm{a}} \pm 0.94$ & $78.06^{\mathrm{b}} \pm 1.65$ & 0.013 \\
& BL & $101.98^{\mathrm{a}} \pm 0.51$ & $104.45^{\mathrm{b}} \pm 0.94$ & 0.026 \\
& HG & $128.27 \pm 0.48$ & $129.21 \pm 0.88$ & 0.349 \\
& WH & $83.38 \pm 0.43$ & $84.12 \pm 0.78$ & 0.414 \\
& RL & $36.91 \pm 0.31$ & $37.77 \pm 0.56$ & 0.190 \\
& CD & $55.48^{\mathrm{a}} \pm 0.25$ & $56.80^{\mathrm{b}} \pm 0.45$ & 0.015 \\
\hline
\end{tabular}

${ }^{\mathrm{ab}}$ Means with different superscript within rows are significantly different $(\mathrm{p}<0.05)$. WF, White Fulani; Mut, Muturu; BL, Body Length; HG, Heart Girth; WH, Wither Height; RL, Rump Length; CD, Chest Depth.

Table S2. Association of C22481T SNP genotypes of SMO exon 11 gene with body measurement traits in White Fulani cattle.

\begin{tabular}{ccccc}
\hline \multirow{2}{*}{ Breed } & \multirow{2}{*}{$\begin{array}{c}\text { Traits } \\
\text { (means in cm } \pm \text { SE) }\end{array}$} & \multicolumn{2}{c}{ Genotype } & \multirow{2}{*}{ P-value } \\
\cline { 3 - 4 } WF (37) & BL & $133.93 \pm 0.78$ & $132.24 \pm 1.97$ & 0.429 \\
& HG & $176.07 \pm 0.96$ & $174.44 \pm 2.42$ & 0.535 \\
WH & $146.41 \pm 0.87$ & $146.96 \pm 2.25$ & 0.823 \\
& RL & $52.60 \pm 0.78$ & $52.70 \pm 1.98$ & 0.964 \\
CD & $74.29 \pm 0.96$ & $73.84 \pm 2.43$ & 0.863 \\
\hline
\end{tabular}

All means within the same row are not significantly different $(\mathrm{P}>0.05)$. WF, White Fulani; BL, Body length; HG, Heart girth; WH, Wither height; RL, Rump length; CD, Chest depth.

Table S3. Association of T22939C SNP genotypes of SMO exon 12 gene with body measurement traits in White Fulani and Muturu cattle.

\begin{tabular}{|c|c|c|c|c|c|}
\hline \multirow{2}{*}{ Breed } & \multirow{2}{*}{$\begin{array}{c}\text { Traits } \\
(\text { means in } \mathrm{cm} \pm \mathrm{SE})\end{array}$} & \multicolumn{3}{|c|}{ Genotype } & \multirow{2}{*}{ P-value } \\
\hline & & $\mathrm{CC}$ & CT & TT & \\
\hline \multirow[t]{5}{*}{ WF (37) } & $\mathrm{BL}$ & $131.86^{\mathrm{a}} \pm 0.72$ & $135.78^{\mathrm{b}} \pm 1.18$ & $133.24^{\mathrm{ab}} \pm 3.34$ & 0.031 \\
\hline & HG & $174.04 \pm 0.90$ & $176.54 \pm 1.46$ & $182.66 \pm 4.12$ & 0.076 \\
\hline & WH & $144.67^{\mathrm{a}} \pm 0.86$ & $149.23^{\mathrm{b}} \pm 1.40$ & $147.56^{\mathrm{ab}} \pm 3.94$ & 0.031 \\
\hline & $\mathrm{RL}$ & $51.40 \pm 0.57$ & $53.13 \pm 0.92$ & $49.78 \pm 2.59$ & 0.221 \\
\hline & CD & $72.58 \pm 0.88$ & $76.53 \pm 1.43$ & $79.24 \pm 4.04$ & 0.096 \\
\hline
\end{tabular}




\section{Continued}

\begin{tabular}{lccccc}
\hline Mut (39) & BL & $98.60^{\mathrm{a}} \pm 0.65$ & $102.78^{\mathrm{b}} \pm 0.58$ & $104.81^{\mathrm{c}} \pm 0.69$ & $<0.001$ \\
& HG & $125.55^{\mathrm{a}} \pm 0.52$ & $127.85^{\mathrm{b}} \pm 0.47$ & $131.98^{\mathrm{c}} \pm 0.56$ & $<0.001$ \\
& WH & $81.57^{\mathrm{a}} \pm 0.59$ & $83.47^{\mathrm{b}} \pm 0.53$ & $85.79^{\mathrm{c}} \pm 0.63$ & $<0.001$ \\
& RL & $35.98^{\mathrm{a}} \pm 0.38$ & $36.94^{\mathrm{a}} \pm 0.34$ & $38.33^{\mathrm{b}} \pm 0.47$ & 0.001 \\
& CD & $54.88 \pm 0.49$ & $55.83 \pm 0.44$ & $56.68 \pm 0.53$ & 0.064 \\
\hline
\end{tabular}

${ }^{\mathrm{abc}}$ Means with different superscript within rows are significantly different ( $\mathrm{p}<0.05$ or 0.001$)$. WF, White Fulani; Mut, Muturu; BL, Body length; HG, Heart girth; WH, Wither height; RL, Rump length; CD, Chest depth.

Table S4. Association of C23329T SNP genotypes of SMO 3'UTR region with body measurement traits in White Fulani and Muturu cattle.

\begin{tabular}{cccccc}
\hline \multirow{2}{*}{ Breed } & Traits & \multicolumn{3}{c}{ Genotype } & P-value \\
\cline { 3 - 5 } (means in cm \pm SE) & CC & CT & TT & \\
\hline WF (39) & BL & $134.02 \pm 0.73$ & $130.46 \pm 2.12$ & $126.80 \pm 4.24$ & 0.094 \\
& HG & $176.23 \pm 0.92$ & $173.07 \pm 2.68$ & $172.45 \mathrm{a} \pm 5.35$ & 0.445 \\
& WH & $147.12 \pm 0.84$ & $143.24 \pm 2.45$ & $145.70 \pm 4.89$ & 0.330 \\
\multirow{3}{*}{ Mut (37) } & RL & $52.78 \pm 0.74$ & $50.77 \pm 2.16$ & $55.10 \pm 4.31$ & 0.578 \\
& CD & $74.25 \pm 0.91$ & $72.71 \pm 2.65$ & $78.55 \pm 5.29$ & 0.612 \\
& BL & $102.79 \pm 0.59$ & $100.60 \pm 1.32$ & $102.28 \pm 2.96$ & 0.319 \\
& HG & $128.89 \pm 0.46$ & $126.44 \pm 1.15$ & $125.70 \pm 2.76$ & 0.095 \\
& WH & $83.80 \pm 0.40$ & $82.43 \pm 0.99$ & $81.36 \pm 2.22$ & 0.283 \\
& RL & $37.17 \pm 0.24$ & $36.56 \pm 0.60$ & $36.50 \pm 1.33$ & 0.591 \\
& CD & $54.91 \pm 0.26$ & $55.18 \pm 0.64$ & $55.12 \pm 1.44$ & 0.522 \\
\hline
\end{tabular}

All means within the same row are not significantly different ( $p>0.05)$. WF, White Fulani; Mut, Muturu; BL, Body length; HG, Heart girth; WH, Wither height; RL, Rump length; CD, Chest depth.

Table S5. Association of T23458G SNP genotypes of SMO 3'UTR region with body measurement traits in White Fulani and Muturu cattle.

\begin{tabular}{|c|c|c|c|c|c|}
\hline \multirow{2}{*}{ Breed } & \multirow{2}{*}{$\begin{array}{c}\text { Traits } \\
(\text { means in } \mathrm{cm} \pm \mathrm{SE})\end{array}$} & \multicolumn{3}{|c|}{ Genotype } & \multirow{2}{*}{$\mathrm{P}$-value } \\
\hline & & TT & TG & GG & \\
\hline \multirow[t]{5}{*}{ WF (38) } & $\mathrm{BL}$ & $135.67^{\mathrm{a}} \pm 1.03$ & $134.67^{\mathrm{a}} \pm 0.99$ & $129.81^{b} \pm 1.12$ & 0.001 \\
\hline & HG & $177.42 \pm 1.43$ & $176.77 \pm 1.38$ & $172.71 \pm 1.55$ & 0.07 \\
\hline & WH & $147.75^{\mathrm{a}} \pm 1.26$ & $148.53^{\mathrm{a}} \pm 1.21$ & $143.27^{\mathrm{b}} \pm 1.39$ & 0.017 \\
\hline & RL & $53.57 \pm 1.20$ & $53.06 \pm 1.15$ & $51.20 \pm 1.30$ & 0.352 \\
\hline & $\mathrm{CD}$ & $75.46 \pm 1.41$ & $75.30 \pm 1.35$ & $71.22 \pm 1.53$ & 0.086 \\
\hline \multirow[t]{5}{*}{ Mut (35) } & $\mathrm{BL}$ & $104.65^{\mathrm{a}} \pm 0.61$ & $102.19^{\mathrm{b}} \pm 0.66$ & $100.37^{\mathrm{b}} \pm 0.76$ & $<0.001$ \\
\hline & $\mathrm{HG}$ & $130.28^{a} \pm 0.59$ & $128.38^{\mathrm{b}} \pm 0.64$ & $126.33^{\mathrm{c}} \pm 0.74$ & 0.001 \\
\hline & WH & $85.07^{\mathrm{a}} \pm 0.52$ & $83.01^{b} \pm 0.56$ & $81.90^{\mathrm{b}} \pm 0.64$ & 0.001 \\
\hline & RL & $37.81^{\mathrm{a}} \pm 0.31$ & $37.13^{\mathrm{a}} \pm 0.34$ & $36.04^{\mathrm{b}} \pm 0.30$ & 0.005 \\
\hline & $\mathrm{CD}$ & $56.26 \pm 0.38$ & $55.83 \pm 0.41$ & $55.15 \pm 0.47$ & 0.195 \\
\hline
\end{tabular}

${ }^{\mathrm{abc}}$ Means with different superscript within rows are significantly different $(\mathrm{p}<0.05$ or 0.001$)$. WF, White Fulani; Mut, Muturu; BL, Body length; HG, Heart girth; WH, Wither height; RL, Rump length; CD, Chest depth. 
Table S6. (a) The original data obtained from the field and the 24-month adjusted data for White Fulani; (b) The original data obtained from the field and the 24-month adjusted data for Muturu.

(a)

\begin{tabular}{|c|c|c|c|c|c|c|c|c|c|c|c|}
\hline $\mathrm{S} / \mathrm{N}$ & Age & $\mathrm{BL}$ & A-BL & $\mathrm{HG}$ & A-HG & WH & A-WH & $\mathrm{RL}$ & A-RL & $\mathrm{CD}$ & A-CD \\
\hline 1 & 23 & 130 & 136.56 & 170 & 177.29 & 136 & 144.64 & 47 & 51.22 & 69 & 73.31 \\
\hline 2 & 24 & 132 & 132 & 171 & 171 & 140 & 140 & 51 & 51 & 72 & 72 \\
\hline 3 & 23 & 127 & 133.56 & 168 & 175.29 & 137 & 145.64 & 48.3 & 52.52 & 73 & 77.31 \\
\hline 4 & 19 & 100 & 132.8 & 138.4 & 174.85 & 103 & 146.2 & 34.5 & 55.6 & 52 & 73.55 \\
\hline 5 & 19 & 96 & 128.8 & 130 & 166.45 & 100 & 143.2 & 32 & 53.1 & 49 & 70.55 \\
\hline 6 & 21 & 110 & 129.68 & 151 & 172.87 & 117 & 142.92 & 36 & 48.66 & 53 & 65.93 \\
\hline 7 & 20 & 107 & 133.24 & 150 & 179.16 & 110 & 144.56 & 32 & 48.88 & 61 & 78.24 \\
\hline 8 & 19 & 98 & 130.8 & 137 & 173.45 & 102 & 145.2 & 33 & 54.1 & 55 & 76.55 \\
\hline 9 & 22 & 120 & 133.12 & 160 & 174.58 & 130 & 147.28 & 46 & 54.44 & 62 & 70.62 \\
\hline 10 & 20 & 109 & 135.24 & 150 & 179.16 & 112 & 146.56 & 35 & 51.88 & 53 & 70.24 \\
\hline 11 & 20 & 104 & 130.24 & 144.6 & 173.76 & 106 & 140.56 & 30 & 46.88 & 61 & 78.24 \\
\hline 12 & 19 & 113 & 145.8 & 142.5 & 178.95 & 109 & 152.2 & 36 & 57.1 & 56 & 77.55 \\
\hline 13 & 23 & 120 & 126.56 & 165.7 & 172.99 & 138 & 146.64 & 49 & 53.22 & 69 & 73.31 \\
\hline 14 & 20 & 107 & 133.24 & 153.5 & 182.66 & 113 & 147.56 & 32.9 & 49.78 & 62 & 79.24 \\
\hline 15 & 19 & 98 & 130.8 & 140 & 176.45 & 103 & 146.2 & 36.8 & 57.9 & 54 & 75.55 \\
\hline 16 & 20 & 110 & 136.24 & 146.5 & 175.66 & 113 & 147.56 & 34.2 & 51.08 & 54 & 71.24 \\
\hline 17 & 23 & 128 & 134.56 & 168 & 175.29 & 139 & 147.64 & 48.5 & 52.72 & 73.5 & 77.81 \\
\hline 18 & 24 & 133 & 133 & 172 & 172 & 145 & 145 & 53 & 53 & 69 & 69 \\
\hline 19 & 23 & 123 & 129.56 & 176 & 183.29 & 142 & 150.64 & 50 & 54.22 & 69 & 73.31 \\
\hline 20 & 20 & 117 & 143.24 & 167 & 196.16 & 130 & 164.56 & 55 & 71.88 & 78 & 95.24 \\
\hline 21 & 21 & 118 & 137.68 & 153 & 174.87 & 127 & 152.92 & 37 & 49.66 & 64 & 76.93 \\
\hline 22 & 22 & 123 & 136.12 & 166.8 & 181.38 & 129 & 146.28 & 45 & 53.44 & 66 & 74.62 \\
\hline 23 & 20 & 112 & 138.24 & 151 & 180.16 & 114 & 148.56 & 35 & 51.88 & 56 & 73.24 \\
\hline 24 & 22 & 122 & 135.12 & 166 & 180.58 & 130 & 147.28 & 47 & 55.44 & 65 & 73.62 \\
\hline 25 & 22 & 119 & 132.12 & 158.5 & 173.08 & 135 & 152.28 & 42 & 50.44 & 64 & 72.62 \\
\hline 26 & 23 & 122 & 128.56 & 165.2 & 172.49 & 135 & 143.64 & 49 & 53.22 & 72.5 & 76.81 \\
\hline 27 & 19 & 94 & 126.8 & 136 & 172.45 & 102.5 & 145.7 & 34 & 55.1 & 57 & 78.55 \\
\hline 28 & 21 & 119 & 138.68 & 156 & 177.87 & 126 & 151.92 & 38 & 50.66 & 65 & 77.93 \\
\hline 29 & 22 & 124 & 137.12 & 158 & 172.58 & 126 & 143.28 & 43 & 51.44 & 65 & 73.62 \\
\hline 30 & 23 & 133 & 139.56 & 171 & 178.29 & 143 & 151.64 & 53 & 57.22 & 75 & 79.31 \\
\hline 31 & 23 & 127 & 133.56 & 167 & 174.29 & 136 & 144.64 & 51.5 & 55.72 & 71 & 75.31 \\
\hline 32 & 21 & 116 & 135.68 & 158 & 179.87 & 130 & 155.92 & 38.6 & 51.26 & 64 & 76.93 \\
\hline 33 & 20 & 104 & 130.24 & 148.5 & 177.66 & 104 & 138.56 & 32 & 48.88 & 48 & 65.24 \\
\hline 34 & 20 & 106 & 132.24 & 146 & 175.16 & 112 & 146.56 & 29 & 45.88 & 54 & 71.24 \\
\hline 35 & 19 & 92 & 124.8 & 135 & 171.45 & 101 & 144.2 & 30 & 51.1 & 47 & 68.55 \\
\hline 36 & 20 & 105 & 131.24 & 145 & 174.16 & 107 & 141.56 & 31 & 47.88 & 48 & 65.24 \\
\hline 37 & 20 & 102 & 128.24 & 146.5 & 175.66 & 110 & 144.56 & 34.5 & 51.38 & 58 & 75.24 \\
\hline 38 & 20 & 107 & 133.24 & 132.5 & 161.66 & 103 & 137.56 & 31 & 47.88 & 50 & 67.24 \\
\hline 39 & 19 & 106 & 138.8 & 139 & 175.45 & 102 & 145.2 & 33 & 54.1 & 51 & 72.55 \\
\hline 40 & 19 & 102 & 134.8 & 137 & 173.45 & 105 & 148.2 & 31 & 52.1 & 52 & 73.55 \\
\hline
\end{tabular}

Age in Months, all traits were measured in centimetres, BL, Body Length; HG, Heart Girth; WH, Wither Height; RL, Rump Length; CD, Chest Depth. Traits with prefix “A” represents 24-months adjusted values. 
(b)

\begin{tabular}{|c|c|c|c|c|c|c|c|c|c|c|c|}
\hline $\mathrm{S} / \mathrm{N}$ & Age & $\mathrm{BL}$ & A-BL & HG & A-HG & WH & A-WH & $\mathrm{RL}$ & A-RL & $\mathrm{CD}$ & A-CD \\
\hline 1 & 24 & 99.5 & 99.5 & 125 & 125 & 83 & 83 & 36 & 36 & 54 & 54 \\
\hline 2 & 23 & 99 & 103.57 & 122.3 & 129.85 & 78 & 82.09 & 34 & 37.02 & 53 & 56.28 \\
\hline 3 & 20 & 88.5 & 106.78 & 100 & 130.2 & 69 & 85.36 & 27.5 & 39.58 & 44 & 57.12 \\
\hline 4 & 23 & 98 & 102.57 & 120 & 127.55 & 79 & 83.09 & 33 & 36.02 & 53 & 56.28 \\
\hline 5 & 24 & 99 & 99 & 126.5 & 126.5 & 84 & 84 & 36 & 36 & 54 & 54 \\
\hline 6 & 21 & 91 & 104.71 & 111 & 133.65 & 74 & 86.27 & 27 & 36.06 & 45 & 54.84 \\
\hline 7 & 23 & 96.5 & 101.07 & 123.5 & 131.05 & 78 & 82.09 & 38.5 & 41.52 & 52 & 55.28 \\
\hline 8 & 22 & 95 & 104.14 & 114 & 129.1 & 73 & 81.18 & 30.5 & 36.54 & 48 & 54.56 \\
\hline 9 & 24 & 101 & 101 & 127 & 127 & 85 & 85 & 38 & 38 & 56 & 56 \\
\hline 10 & 23 & 95 & 99.57 & 120 & 127.55 & 75 & 79.09 & 32 & 35.02 & 53 & 56.28 \\
\hline 11 & 21 & 89 & 102.71 & 105 & 127.65 & 69 & 81.27 & 27 & 36.06 & 47 & 56.84 \\
\hline 12 & 22 & 94 & 103.14 & 113.5 & 128.6 & 74.5 & 82.68 & 29 & 35.04 & 48 & 54.56 \\
\hline 13 & 21 & 92 & 105.71 & 106 & 128.65 & 68 & 80.27 & 23 & 32.06 & 48 & 57.84 \\
\hline 14 & 23 & 103 & 107.57 & 124 & 131.55 & 83.5 & 87.59 & 35 & 38.02 & 55 & 58.28 \\
\hline 15 & 24 & 102 & 102 & 127 & 127 & 85 & 85 & 38 & 38 & 57 & 57 \\
\hline 16 & 23 & 96 & 100.57 & 121 & 128.55 & 78 & 82.09 & 34 & 37.02 & 53 & 56.28 \\
\hline 17 & 22 & 98 & 107.14 & 115 & 130.1 & 76 & 84.18 & 32.5 & 38.54 & 52 & 58.56 \\
\hline 18 & 20 & 84 & 102.28 & 95.5 & 125.7 & 65 & 81.36 & 24.5 & 36.58 & 42 & 55.12 \\
\hline 19 & 19 & 75 & 97.85 & 86 & 123.75 & 60.9 & 81.35 & 21 & 36.1 & 39 & 55.4 \\
\hline 20 & 19 & 78 & 100.85 & 89 & 126.75 & 64.1 & 84.55 & 21.5 & 36.6 & 40 & 56.4 \\
\hline 21 & 19 & 76 & 98.85 & 88 & 125.75 & 61 & 81.45 & 21.5 & 36.6 & 41 & 57.4 \\
\hline 22 & 19 & 74 & 96.85 & 86 & 123.75 & 61.5 & 81.95 & 22 & 37.1 & 39 & 55.4 \\
\hline 23 & 20 & 87 & 105.28 & 98.5 & 128.7 & 71 & 87.36 & 27 & 39.08 & 41 & 54.12 \\
\hline 24 & 22 & 97 & 106.14 & 114 & 129.1 & 75 & 83.18 & 31.5 & 37.54 & 50 & 56.56 \\
\hline 25 & 23 & 100 & 104.57 & 124 & 131.55 & 83 & 87.09 & 36 & 39.02 & 54 & 57.28 \\
\hline 26 & 24 & 96 & 96 & 125 & 125 & 82.5 & 82.5 & 36 & 36 & 54 & 54 \\
\hline 27 & 23 & 98 & 102.57 & 121 & 128.55 & 78 & 82.09 & 35 & 38.02 & 53 & 56.28 \\
\hline 28 & 24 & 102 & 102 & 126 & 126 & 85 & 85 & 37 & 37 & 55 & 55 \\
\hline 29 & 21 & 91 & 104.71 & 112 & 134.65 & 75 & 87.27 & 30 & 39.06 & 44 & 53.84 \\
\hline 30 & 20 & 87 & 105.28 & 98 & 128.2 & 67 & 83.36 & 23 & 35.08 & 41 & 54.12 \\
\hline 31 & 23 & 101 & 105.57 & 124 & 131.55 & 83 & 87.09 & 35 & 38.02 & 55 & 58.28 \\
\hline 32 & 22 & 92 & 101.14 & 112 & 127.1 & 71 & 79.18 & 29 & 35.04 & 46 & 52.56 \\
\hline 33 & 23 & 96 & 100.57 & 121 & 128.55 & 81.9 & 85.99 & 36 & 39.02 & 53 & 56.28 \\
\hline 34 & 19 & 79 & 101.85 & 94 & 131.75 & 65.5 & 85.95 & 23 & 38.1 & 40 & 56.4 \\
\hline 35 & 20 & 88 & 106.28 & 96.5 & 126.7 & 67 & 83.36 & 25 & 37.08 & 41 & 54.12 \\
\hline 36 & 22 & 95 & 104.14 & 115 & 130.1 & 72 & 80.18 & 29.5 & 35.54 & 48 & 54.56 \\
\hline 37 & 19 & 78 & 100.85 & 95.5 & 133.25 & 65 & 85.45 & 25 & 40.1 & 41 & 57.4 \\
\hline 38 & 22 & 97 & 106.14 & 114 & 129.1 & 75 & 83.18 & 31 & 37.04 & 50 & 56.56 \\
\hline 39 & 20 & 86 & 104.28 & 100.5 & 130.7 & 66 & 82.36 & 25 & 37.08 & 43 & 56.12 \\
\hline 40 & 19 & 76 & 98.85 & 88 & 125.75 & 65 & 85.45 & 22 & 37.1 & 38 & 54.4 \\
\hline
\end{tabular}

Age in Months, all traits were measured in centimetres, BL, Body length; HG, Heart Girth; WH, Wither Height; RL, Rump Length; CD, Chest Depth. Traits with prefix "A" represents 24-months adjusted values. 